\title{
Tissue Localization of $\beta$ Receptors for Platelet-derived Growth Factor and Platelet-derived Growth Factor B Chain during Wound Repair in Humans
}

\author{
Christina Reuterdahl, * Christian Sundberg, ${ }^{\text {*3 }}$ Kristofer Rubin, * Keiko Funa, ${ }^{\star}$ and Bengt Gerdin" \\ ${ }^{*}$ Department of Medical and Physiological Chemistry, Biomedical Center, S-751 23 Uppsala, Sweden; ${ }^{\ddagger}$ Ludwig Institute of Cancer \\ Research, Biomedical Center, S-751 24 Uppsala, Sweden; and ${ }^{\S}$ Department of Surgery, University Hospital, S-751 85 Uppsala, Sweden
}

\begin{abstract}
The expression and localization of PDGF $\beta$ receptors and PDGF-AB / BB in human healing wounds was evaluated by immunohistochemical techniques and in situ hybridization. Expression of PDGF $\beta$ receptor protein and PDGF-AB/BB were analyzed in wound margin biopsies using the PDGFR-B2 and PDGF 007 antibodies. PDGF $\beta$ receptor expression was minor in normal skin. An increased expression of PDGF $\beta$ receptor protein was prominent in vessels in the proliferating tissue zone in wounds as early as $1 \mathrm{~d}$ after surgery and was apparent $\leq 4 \mathrm{wk}$ after surgery. There was also a concordant increase in PDGF $\beta$ receptor mRNA detected by in situ hybridization. PDGF-AB/ BB was present in healing wounds as well as in normal skin. In normal skin, expression of PDGF-AB / BB was confined to peripheral nerve fibers and to solitary cells of the epidermis and of the superficial dermis. In wounds, infiltrating mononuclear cells also stained for PDGF-AB/BB. To identify cell types expressing PDGF AB/BB and PDGF $\beta$ receptors, respectively, we performed double immunofluorescence stainings. PDGF $\beta$ receptors were expressed by vascular smooth muscle cells and cells in capillary walls; the receptor protein could not be detected in neurofilament containing structures, $T$ lymphocytes, or CD68 expressing macrophages. PDGF-AB / BB colocalized with neurofilaments, it was present in Langerhans cells of the epidermis and in HLA-DR positive cells located in the epidermal/dermal junction area. Of the macrophages infiltrating the wound, $43 \pm 18 \%$ stained positively for PDGF AB /BB. Since PDGF-AB/BB and PDGF $\beta$ receptors are expressed in the healing wound, two essential prerequisites for a role of PDGF in wound healing are fulfilled. (J. Clin. Invest. 1993. 91:2065-2075.) Key words: PDGF • PDGF receptor • extracellular matrix • wound healing • man • immunohistochemistry
\end{abstract}

\section{Introduction}

Trauma and damage to tissues are followed by a healing process during which connective tissue cells become activated to proliferate and produce components of the extracellular matrix. Certain characteristics of this process are quite similar to conditions in which tissue fibrosis is a consequence of chronic inflammation, such as scleroderma, Crohn's disease, and RA.

Address correspondence to Bengt Gerdin, M.D., Ph.D., Department of Surgery, University Hospital, S-751 85 Uppsala, Sweden.

Received for publication 14 January 1992 and in revised form 14 December 1992.

J. Clin. Invest.

(C) The American Society for Clinical Investigation, Inc.

$0021-9738 / 93 / 05 / 2065 / 11 \$ 2.00$

Volume 91, May 1993, 2065-2075
The initial signals which cause activation of connective tissue cells in these conditions are poorly understood. However, it is generally agreed that such activation is caused by an integrated signaling from inflammatory cells to connective tissue cells, a process in which growth factors play a central role (1-3).

Clinical studies, as well as studies in experimental animal models, have shown that locally applied PDGF stimulates wound healing (4-7). Structurally PDGF is a dimer composed of two disulfide-bonded chains, denoted $A$ and $B$. All three possible PDGF dimers; i.e., PDGF-AA, -AB, and -BB, have been isolated from natural sources $(8-10)$. While all forms of PDGF stimulate cultured cells of mesodermal origin to proliferate $(8,9,11)$ and stimulate fibroblast mediated contraction of hydrated collagen gels (12-14), only PDGF-AB/BB acts chemotactically $(8,9,15)$. Furthermore, PDGF-BB is more potent than PDGF-AA in stimulating wound healing in the rat (16). The role of PDGF B chain in promoting growth of connective tissue is also supported by the observation that transfection of PDGF B chain to human melanoma alters the characteristics of tumor growth from a phenotype with virtually no stroma, to a phenotype with an excess of well-vascularized fibrous stroma (17).

PDGF is produced by a variety of cultured cells including cells of the monocyte/macrophage lineage $(8,9,11)$. Possible adjustment of PDGF production and function by cells of the immune system is indicated by the fact that some macrophagederived cytokines, such as TNF- $\alpha$, IL- 1 , TGF- $\beta$, and PDGF itself, can regulate the expression of PDGF genes $(8,9)$. In addition, IL- 1 and TNF- $\alpha$ have been shown to inhibit the response to PDGF by target cells $(14,18)$.

All forms of PDGF exert their effect after binding to two similar but distinct high affinity membrane receptors, the $\alpha$ and $\beta$ receptors $(8,9,19,20)$. The $\alpha$ receptor binds all three PDGF dimers, whereas the $\beta$ receptor binds PDGF-BB and, with lower affinity, PDGF-AB $(8,9,19,20)$. Ligand stimulation of PDGF $\alpha$ and $\beta$ receptors leads to activation of signal tranduction pathways. These pathways are in part common for the two receptors, and in part unique. Thus, it has been shown that receptor-stimulated $\beta$ receptors phosphorylate a partly different subset of intracellular proteins than the $\alpha$ receptor (21). These findings provide a possible molecular background to the in part different cell physiological responses of PDGF-AA and PDGF-AB/BB, respectively. The expression of PDGF $\alpha$ and $\beta$ receptors is also likely to be under separate control, since cells can express one or the other, or both $(8,9)$.

In our earlier immunohistochemical evaluations of the PDGF $\beta$ receptor expression in vivo, we have used two monoclonal antibodies, denoted PDGFR-B1 and PDGFR-B2, that specifically recognize the PDGF $\beta$ receptor $(19,22)$. Previous results indicate a low to absent expression of PDGF $\beta$ receptors in normal, adult connective tissues, such as human dermis, synovia, and in the tunica media of arteries (23-25). A corre- 
sponding absence of PDGF $\beta$ receptor $\mathrm{mRNA}$ was observed by in situ hybridization $(25,26)$. Wilcox et al. similarly reported on a low expression of PDGF $\beta$ receptor mRNA in normal arteries (27). PDGF $\beta$ receptors are, however, present in capillary cells and neurons in the normal adult rat brain $(27,28)$.

Neoexpression of PDGF $\beta$ receptor protein and mRNA occurs in several inflammatory conditions $(23,24,26,27,29)$. It is particularly evident in vascular cells located in areas rich in HLA-DR expressing cells, $T$ lymphocytes and macrophages $(23,24,26)$. In inflammatory synovitis PDGF $\beta$ receptors are expressed by vascular smooth muscle cells and cells in capillary walls. In contrast, infiltrating $\mathrm{T}$ lymphocytes and a majority of the macrophages were found not to express PDGF $\beta$ receptors $(26)$.

In rheumatoid synovium, PDGF B chain protein is present in the synovial lining cell layer and in macrophage-like cells of the sublining tissue (30). Similarly, in scleroderma, macrophages and cells of the capillary wall express PDGF $B$ chain (31). In atherosclerotic plaques, PDGF-AB/BB was expressed predominantly by macrophages as revealed by immunohistochemistry based on the PDGF-AB/BB specific monoclonal antibody PDGF $007(32,33)$. PDGF AB/BB is also present in the central nervous system (33). PDGF $B$ chain mRNA is present in arterial endothelial cells (27) and in unidentified cells in rheumatoid synovium (26). PDGF A chain mRNA has been detected in intimal smooth muscle cells in fibrotic atherosclerotic plaques (27) and in neurons in the central nervous system (34).

In the present study, we have used immunohistochemistry and in situ hybridization to evaluate the expression of PDGF $\beta$ receptors in biopsies taken from wound edges of surgical incisions during and after elective surgery in humans. We have also identified cell types expressing PDGF $\beta$ receptors. To investigate the possible source of PDGF-AB/BB, (i.e., the ligands for the upregulated PDGF $\beta$ receptors), we surveyed the presence of PDGF AB/BB in specimens from wounds using the PDGF 007 monoclonal antibody.

\section{Methods}

Biopsy material. Repeated biopsies were taken from 10 patients undergoing elective surgery (Table I). In addition, biopsies were taken from healthy skin and intestine during elective surgery, and from the sciatic nerve during lower leg amputation due to occlusive arteriosclerosis. The tissue samples were stored in saline for $>20 \mathrm{~min}$ and were thereafter trimmed and frozen in isopenthane chilled by $\mathrm{CO}_{2}$ to $-70^{\circ} \mathrm{C}$ and subsequently cryo-sectioned.

The study was approved by the Human Ethics Committee of the Uppsala University.

Antibodies. The mouse monoclonal PDGFR-B2, used in this study has been described elsewhere (22). It specifically stains PDGF $\beta$-receptors $(19,22)$. The monoclonal PDGF 007, raised toward a synthetic peptide corresponding to amino acid residues 73-97 fragment of the PDGF B chain (35) was kindly donated to K. Funa by Mochida Pharmaceutical Company (Tokyo, Japan). The latter antibody specifically stains PDGF-AB or PDGF-BB $(32,33)$, so that it has been concluded that positive staining represents the presence of either dimer (here denoted as PDGF-AB/BB). The mouse monoclonal antibodies E 11 and G11, reacting with parathyroid cells and tubular cells in the kidney (36), were used as negative controls and were donated by Dr. C. Juhlin (Dept. of Surgery, University of Uppsala), the monoclonal anti- $\alpha$ smooth muscle actin came from Sigma Immunochemicals (St. Louis, $\mathrm{MO}$ ), the monoclonal mouse antibody to human macrophages (antiCD68, Dako-Macrophage) came from Dakopatts (Glostrup, Denmark), the monoclonal mouse antimacrophage antibody RFD7 (37) was kindly provided by Dr. Leonard Poulter (Department of Immunology, Royal Free Hospital, London ), and monoclonal antibodies Leu-4 (anti-CD3) and anti-HLA-DR came from Becton Dickinson (Mountainview, CA). The antineurofilament antibodies NN18 (monoclonal antineurofilament 160) and 2F11 came from Sigma Immunochemicals and Dakopatts, respectively. Biotinylated anti-mouse IgG, made in horse was from Vector Laboratories (Burlingame, CA), and goat anti-mouse Ig fluorescein conjugate came from Becton Dickinson. Staining of endothelial cells was performed (Ulex Europaeus Agglutinin 1 Fluorescein Conjugate; Vector Laboratories), which binds to blood group $\mathrm{H}$ antigen on the surface of endothelial cells (38). Texas red avidin D came from Vector. All antibodies were diluted in PBS and used in optimal concentrations determined after serial dilution.

Immunohistochemical staining procedure. Frozen sections were fixed in acetone, and endogenous peroxidase was exhausted by $\mathrm{H}_{2} \mathrm{O}_{2}$, blocked with normal horse serum and with avidin/biotin blocking kit (Vector Laboratories), and subsequently subjected to immunohistochemical staining using avidin/biotin enhanced peroxidase staining (Vector Laboratories).

Double immunofluorescence staining. Frozen sections were fixed in acetone, blocked with normal horse serum, followed by an avidin/biotin blocking kit (Vector Laboratories). Sections were then incubated with PDGFR-B2 $(\leq 1 \mu \mathrm{g} / \mathrm{ml})$ or PDGF $007(\leq 1 \mu \mathrm{g} / \mathrm{ml})$ for $45 \mathrm{~min}$, washed, and further incubated with biotinylated horse anti-mouse IgG for $30 \mathrm{~min}$. After washing, the sections were incubated with Texas red avidin for $30 \mathrm{~min}$. The sections were subsequently incubated with the

Table I. Description of the Patients Studied

\begin{tabular}{|c|c|c|c|c|c|c|}
\hline $\begin{array}{l}\text { Patient } \\
\text { number }\end{array}$ & Initials & Age & Sex & Type of surgery & $\begin{array}{l}\text { Location } \\
\text { of biopsy }\end{array}$ & $\begin{array}{c}\text { Days between } \\
\text { biopsy and surgery }\end{array}$ \\
\hline & & $y r$ & & & & \\
\hline 1 & EJ & 76 & $\mathbf{F}$ & Rectopexy & Laparotomy wound & $0,1,2,3,4,5,6,10,12,14$ \\
\hline 2 & $\mathrm{JN}$ & 66 & $\mathbf{F}$ & Abdominoperineal resection & Laparotomy wound & $0,1,2,3,4,5,6,10,12$ \\
\hline 3 & IM & 64 & $\mathbf{F}$ & Proctectomy and hysterectomy & Laparotomy wound & 0,28 \\
\hline 4 & MK & 31 & $\mathbf{M}$ & Excision of fistulae & Right buttock & $2,3,6,7,22$ \\
\hline 5 & AA & 73 & $\mathbf{M}$ & Abdominoperineal resection & Laparotomy wound & 28 \\
\hline 6 & JS & 23 & $\mathbf{M}$ & Pilonidal sinus & Left buttock & 8 \\
\hline 7 & AA & 67 & $\mathbf{M}$ & Abdominoperineal resection & Laparotomy wound & 7 \\
\hline 8 & BB & 92 & $\mathrm{~F}$ & Gastric resection & Laparotomy wound & 7 \\
\hline 9 & SO & 18 & $\mathrm{~F}$ & Appendectomy & Laparotomy wound & 6 \\
\hline 10 & RL & 82 & $\mathbf{M}$ & Cholecystectomy & Laparotomy wound & 6 \\
\hline
\end{tabular}




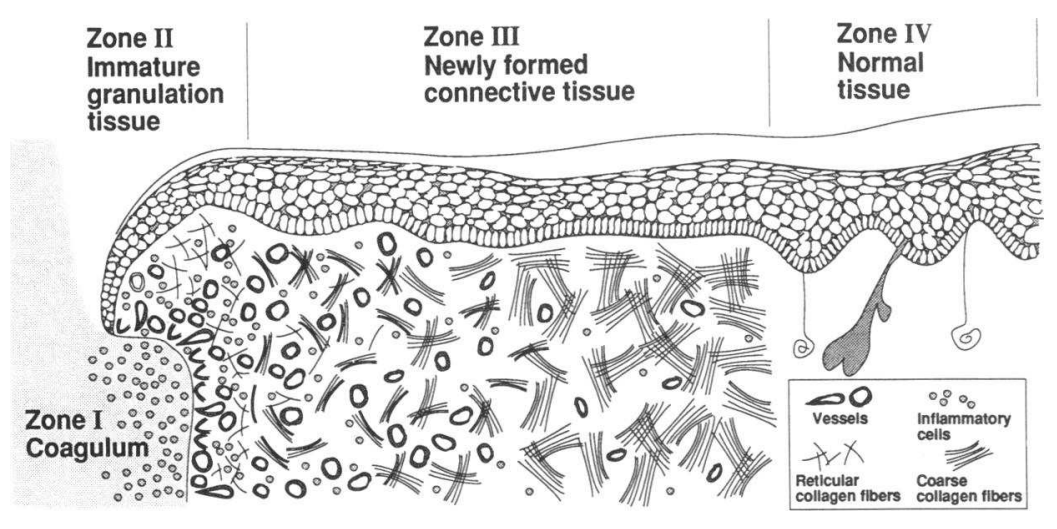

Figure 1. Schematic presentation of the different regions of the healing wound. second primary antibody for $30 \mathrm{~min}$, washed, and finally incubated with the goat anti-mouse IgG fluorescein conjugate for $30 \mathrm{~min}$. All incubations were performed at room temperature. The mounting media used was Fluoromount $\mathrm{G}$ from Southern Biotechnology Inc. (Birmingham, AL).

Controls included the following: $(a)$ exchange of the PDGFR-B2 IgG or PDGF $007 \mathrm{IgG}$ with the E11 or G11 IgG, as well as with other antibodies with different specificities and staining patterns; $(b)$ exchange of IgG for PBS in the staining procedure in all combinations necessary to conclude that the observed staining was adequate; and $(c)$ incubation of PDGF 007 IgG with recombinant PDGF-AA, PDGF-BB or buffer, respectively, at various $\mathrm{IgG} /$ antigen ratios. Incubation with PDGF-BB, but not with PDGF-AA, resulted in a loss of the specific staining. It should be pointed out that the isoelectric points for fragments corresponding to the positions 73-97 are similar in the PDGF A and $B$ chains, respectively. A similar test for specificity of staining with PDGFR-B2 IgG performed as described previously (26).

In situ hybridization. The procedure used and the characteristics of the RNA probe for PDGF $\beta$ receptors have been detailed previously $(26,39)$. The hybridization signals were detected by autoradiography as described (40), and the tissue sections were stained with hematoxylin and eosin after development of the silver grains.

Microscopic evaluation. Sections were evaluated in a conventional light microscope or in a Nikon Optiphot microscope equipped for immunofluorescence. The localization of PDGF $\beta$ receptors or PDGF$\mathrm{AB} / \mathrm{BB}$ positive cells in the wound was evaluated and described in relation to ad hoc identified zones of the healing wound (Fig. 1).

\section{Results}

Temporal analysis of the expression of PDGF $\beta$ receptors and $P D G F-A B / B B$ in healing wounds. In biopsies taken from normal undamaged skin, only a minor expression of PDGF $\beta$ receptors in small subepidermal blood vessels was detected with immunohistochemical staining. This was in accordance with previously obtained results (25). At the concentration of PDGFR-B2 IgG used ( $\leq 1 \mu \mathrm{g} / \mathrm{ml}$ ), the staining was discretely granular (Fig. $2 \mathrm{~A}$, arrows). The number of cells exhibiting such granular accumulations, as well as the number of granules per cell were low in biopsies from normal skin. In agreement with earlier findings (25), no discernible expression of PDGF $\beta$ receptor mRNA was detected in cryosections from normal skin by in situ hybridization (data not shown).

As early as $1 \mathrm{~d}$ after surgery, an enhanced immunoexpression of PDGF $\beta$ receptors in vascular cells of vessels located in the vicinity of the wound edge was detected. $2 \mathrm{~d}$ after surgery, both the number of cells exhibiting granular accumulations of PDGF $\beta$ receptors, as well as the number of granules per cells, was increased (Fig. $2 \mathrm{~B}$, arrows). The enhanced immunoex- pression of PDGF $\beta$ receptors was present in all biopsies taken $1 \mathrm{~d}$ after surgery and onwards; the latest biopsies were taken between days 14 and 28 in the different patients (Table II). A concordant increase in PDGF $\beta$ receptor mRNA was detected by in situ hybridization in healing wounds; PDGF $\beta$ receptor mRNA expression was observed in cells located in the proliferating granulation tissue and also in the original dermis adjacent to the wound edge (Fig. 3).

The expression of PDGF-AB/BB was investigated using the monoclonal antibody PDGF 007 in normal and wounded skin. In contrast to the virtual absence of PDGF $\beta$ receptors in normal human skin, there was a distinct staining for PDGFAB/BB at several locations. Thus, structures that by morphological criteria were identified as nerve fibers stained positively with PDGF 007 IgG (Fig. 4, $A$ and $B$ ). Distinct staining was also observed in isolated cells in the epidermis and in the epidermal-dermal junction (Fig. $4 C$ ). Apart from the staining of nerve fiber-like structures, there were no PDGF-AB/BB-positive cells in the dermis. In some sections, there was also a diffuse staining in the entire epidermis, the nature of which is unclear.

Already $1 \mathrm{~d}$ after wounding, cells staining for PDGF-AB/ BB appeared in the dermis close to the wound edge. In biopsies taken at later time points scattered cells, mostly located in the developing granulation tissue, expressed PDGF-AB/BB (Fig. $4 D$ ).

Characterization of PDGFR- $\beta$ - and PDGF-AB/BB-expressing cells in healing wounds. Double immunofluorescence staining with the PDGFR-B2 and PDGF 007 monoclonal anti-

Table II. Immunoexpression of PDGF $\beta$ Type Receptors Various Times after Wounding; the Patients Are Described in Table I

\begin{tabular}{|c|c|c|c|c|c|c|c|c|c|c|c|c|c|}
\hline \multirow{2}{*}{$\begin{array}{l}\text { Patient } \\
\text { number }\end{array}$} & \multicolumn{13}{|c|}{ Days after surgery } \\
\hline & 0 & 1 & 2 & 3 & 4 & 6 & 7 & 10 & 12 & 14 & 22 & 27 & 28 \\
\hline 1 & $(-)$ & $(+)$ & + & + & + & + & + & + & + & + & & & \\
\hline 2 & $(-)$ & $(+)$ & + & + & + & + & + & + & + & & & & \\
\hline 3 & $(-)$ & & & & & & & & & & & + & \\
\hline 4 & & & + & + & & + & + & & & & + & & \\
\hline 5 & & & & & & & & & & & & & + \\
\hline
\end{tabular}

$(-)$, No expression, except a very faint signal from a few vessels; +, faint expression in small vessels, more profound along the wound edge; $(+)$, definite expression, most prominent in vessels and along the wound edge. 

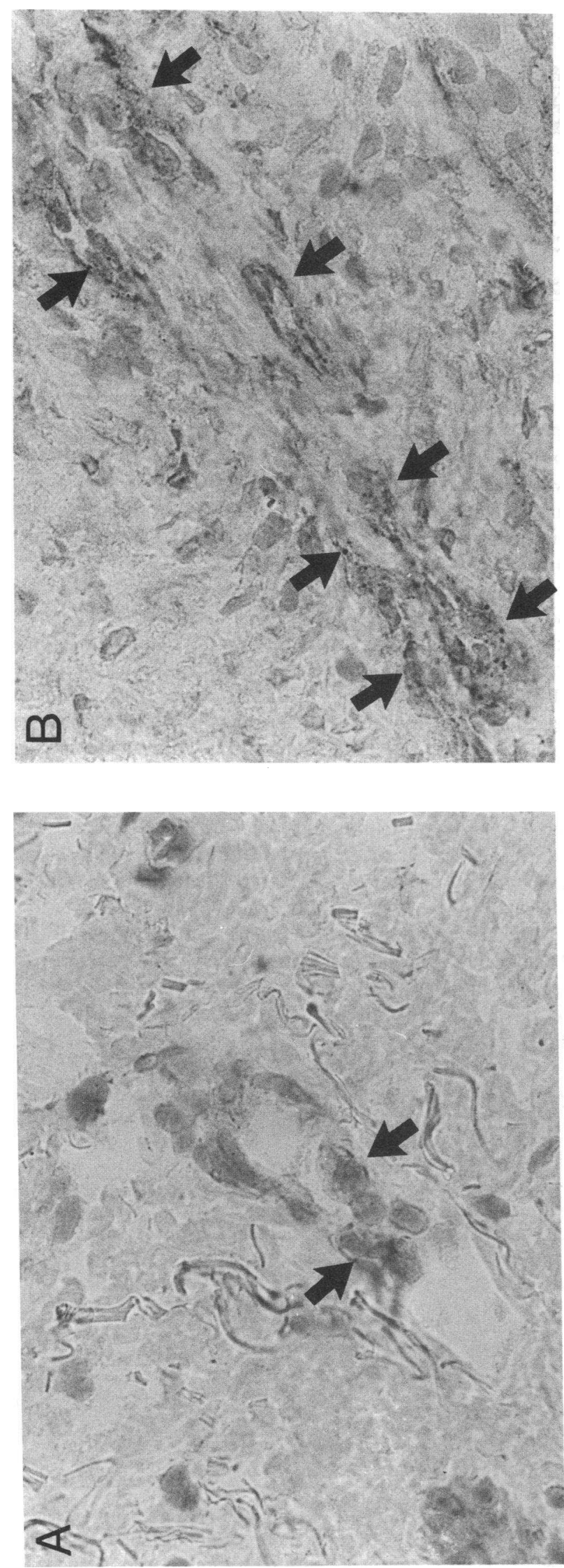

bodies and various antibodies for cell type-specific antigens were used to characterize cells expressing PDGF $\beta$ receptors and PDGF-AB/BB, respectively. The distribution of PDGF $\beta$ receptor-expressing cells in healing wounds was found to resemble that observed in rheumatic synovia (26). Thus, in healing wounds PDGF $\beta$ receptors were expressed by smooth muscle cells (data not shown) and in capillary walls (Fig. 5). In contrast, neither CD68-positive macrophages (Fig. 6, $A$ and $B), T$ lymphocytes (not shown), nor cells expressing HLA-DR (not shown) expressed PDGF $\beta$ receptors.

The PDGF 007 staining observed in nerve fiber-like structures colocalized with staining for neurofilament in both normal skin and in skin adjacent to healing wounds, indicating the presence of PDGF-AB/BB in peripheral nerve fibers (Fig. 7). The resolution of the double immunofluorescence stainings did not allow for a definite assessment of the localization of PDGF 007 stain within the nerves of the skin specimens.

The PDGF-AB/BB-positive cells in the epidermis were identified as Langerhans cells, since they also expressed HLADR (data not shown). Likewise, most of the PDGF-AB/BB positive cells in the epidermal-dermal junction expressed HLA-DR.

Double immunofluorescence was also used to investigate the number of CD68-positive macrophages that expressed PDGF-AB/BB. This type of analysis was performed in the eight patients where biopsies were taken 6-8 d after surgery and in three normal skin biopsies (Table III). In normal skin, CD68-positive macrophages were only localized in the epidermal-dermal border zone (Table III). $15 \%$ of those macrophages expressed PDGF B chain and $10 \%$ of all cell expressing PDGF B chain were CD68 positive macrophages. In the 6-8-dold wounds, $35 \pm 11 \%$ of the superficial dermal macrophages expressed PDGF B chain, and $43 \pm 18 \%$ of the superficial cells expressing PDGF $B$ chain were macrophages. A similar relative distribution of PDGF-AB/BB-expressing cells was seen in the population of macrophages identified by the antibody RFD7 (data not shown).

The nature of the PDGF 007+/CD68 cells is not known. However, the morphological characteristics of the PDGF 007+/CD68+ and PDGF 007+/CD68 cells were largely similar. They were large and either rounded or of a stellate shape. A frequent observation was an apparent juxtaposition of cells characterized by PDGF 007-/CD68+ and PDGF 007+/ CD68-, respectively (data not shown).

Structural localization of $P D G F \beta$ receptor and $P D G F-A B /$ $B B$-expressing cells during wound healing. The fibrinoid unvascularized matrix of the wound edge (Fig. 1, Zone I) was always negative, both with regards to PDGF $\beta$ receptors and to PDGF-AB/BB. Facing the wound edge (Zone II), the front of the capillary sprouts in the granulation tissue were regularly negative for PDGF $\beta$ receptors. However, staining of capillary walls appeared only $100-300 \mu \mathrm{m}$ deeper down in the granulation tissue. In those cells, the coarse granular characteristics of the staining was obvious (Fig. $5 A$ ). Deeper in the wound, where the vascular density and the number of inflammatory

Figure 2. Immunohistochemical staining of nonwounded skin specimen from patient 1 using PDGFR-B2 $\mathrm{IgG}$ at $1 \mu \mathrm{g} / \mathrm{ml}(A)$ showing a weak staining of smaller vessels in the papillary dermis. In 28-d-old granulation tissue, there is a considerably more intense staining ( $B$; specimen from patient 5 ). 

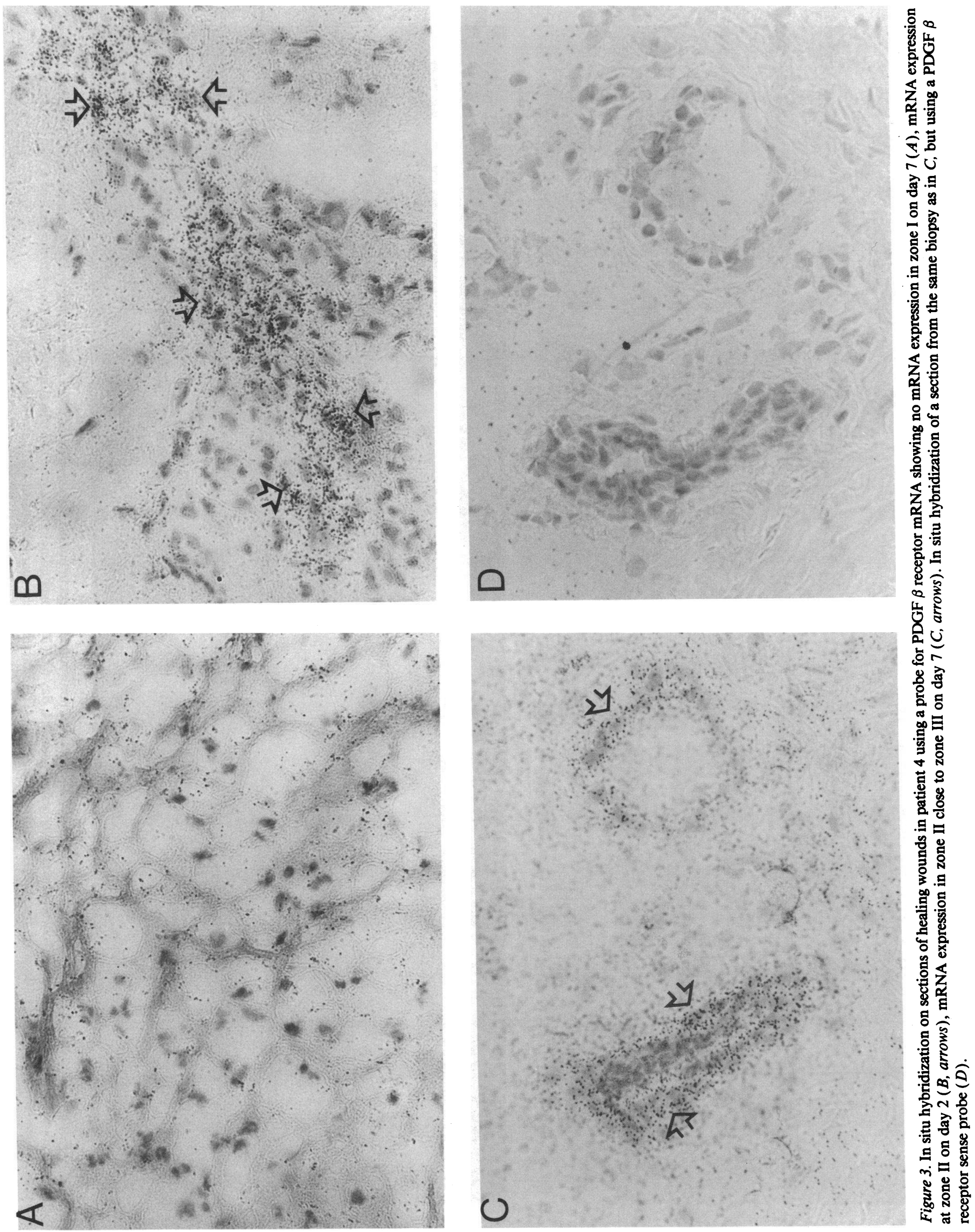

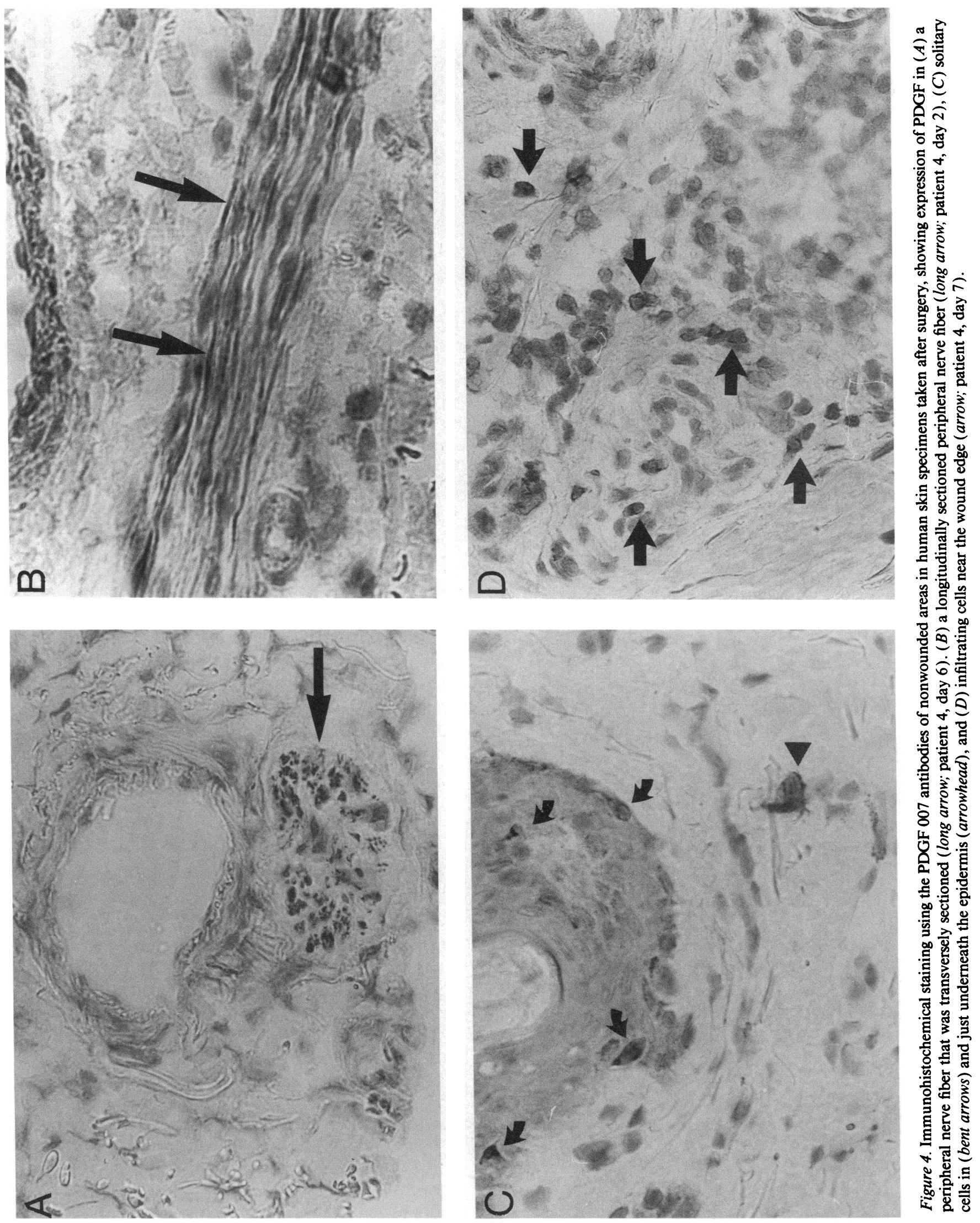

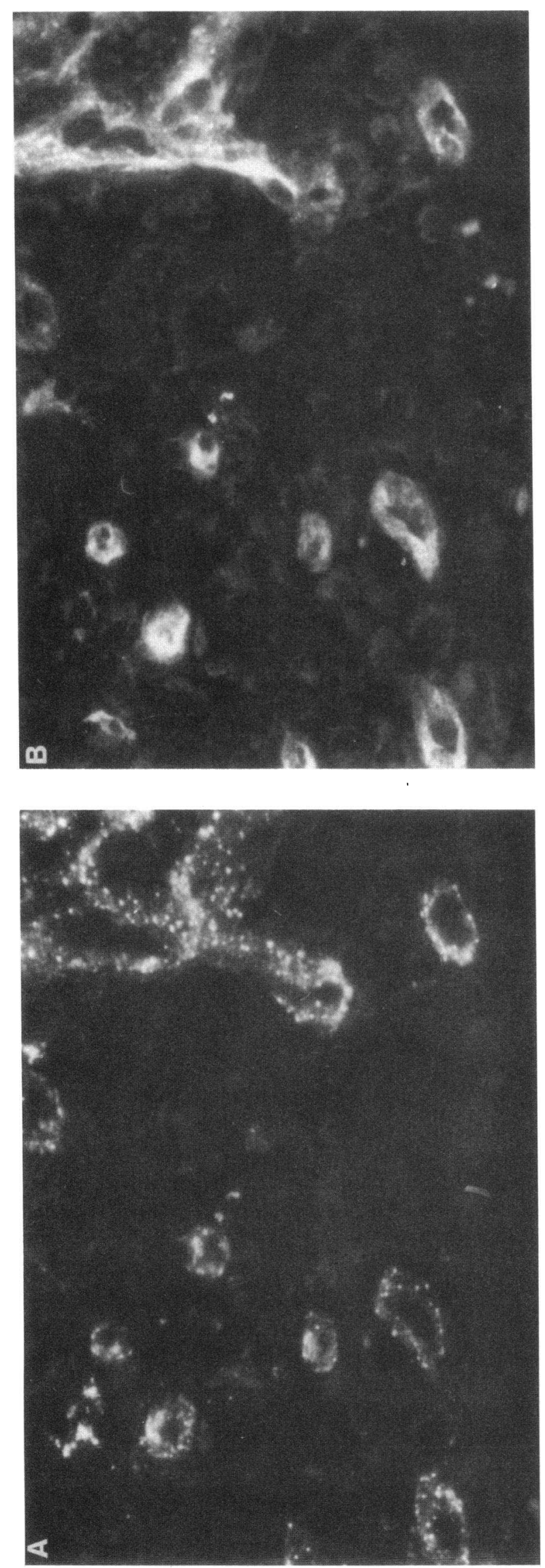

cells were less pronounced, and where coarse irregular bundles of collagen were seen (Zone III), the capillary walls still stained for PDGF $\beta$ receptors, however, seemingly with slightly less intensity. In the undamaged neighboring healthy dermis (Zone $I V)$, the staining intensity was weaker.

Staining for PDGF-AB/BB in nerves was observed in the normal tissue (Zone $I V$ ). It should be emphasized that no PDGF-AB/BB expressing nerves were detected in zones I-III (Fig. 1); i.e., in parts with newly formed tissues that are not innervated. In the wound zones II and III, however, there was an infiltration of PDGF-AB/BB cells, of which, as stated above, a considerable fraction were identified as macrophages.

\section{Discussion}

Wounding of human skin resulted in an increased immunoexpression of PDGF $\beta$ receptors, particularly in the vasculature; this neoexpression was evident already 1-2 d after surgery. Infiltrating T lymphocytes, HLA-DR expressing cells, and macrophages did not express PDGF $\beta$ receptors. The latter cells were frequently found close to vessels harboring PDGF $\beta$ receptor positive cells, suggesting that bone marrow-derived cells regulate the expression of PDGF $\beta$ receptors and/or the availability of PDGF-AB/BB. The distribution of PDGF $\beta$ receptor-positive cells in wounds resembles that seen in rheumatoid synovia in support of our previous suggestion that neoexpression of PDGF $\beta$ receptors is part of a common pathway in inflammatory conditions (24). It should, however, be emphasized that PDGF $\beta$ receptor expression can also be induced by noninflammatory reactions; i.e., during adaption to cell culture conditions (24) or by certain tumors (41).

PDGF $\beta$ receptor mRNA expression was also increased in wounds. Based on morphological criteria, PDGF $\beta$ receptor mRNA expressing cells included cells in vessel walls, but also stromal cells located in the vicinity of vessels. When detected by immunostaining, PDGF $\beta$ receptors were most prominently expressed by vascular cells. However, it cannot be excluded that stromal cells located around vessels (e.g., perivascular fibroblasts) also expressed PDGF $\beta$ receptors, in analogy to the observation in cultured fibroblasts $(8,9,11)$. In fact, the immunostainings are compatible with such a notion (Figs. $2 B$ and 6 $A$ ). Because of a lack of reagents suitable for the identification of fibroblasts by immunostaining, it was not possible to determine conclusively if fibroblasts in wounds expressed PDGF $\beta$ receptors or not.

The capillary wall lining in normal adult arteries has previously been found not to express PDGF receptors $(23,26)$. This is in agreement with the finding that cultured aortic endothelial cells lack PDGF receptors $(8,9,11,24)$. However, capillary endothelial cells express PDGF receptors both in vitro and in vivo (41-43). In the present report, we demonstrate that PDGF $\beta$ receptors are present in the lining of capillary walls, similar to capillaries in rheumatoid synovia (26). With the present methodology, it was not possible to conclude which cell type that expressed PDGF $\beta$ receptors in capillaries in the healing wound. Although the double immunofluorescence stain-

Figure 5. Double immunofluorescence staining of a healing wound (patient 4, day 7) showing staining for PDGF $\beta$ receptors $(A)$ in vessels identified by the endothelial specific lectin Ulex europeus $(B)$. 

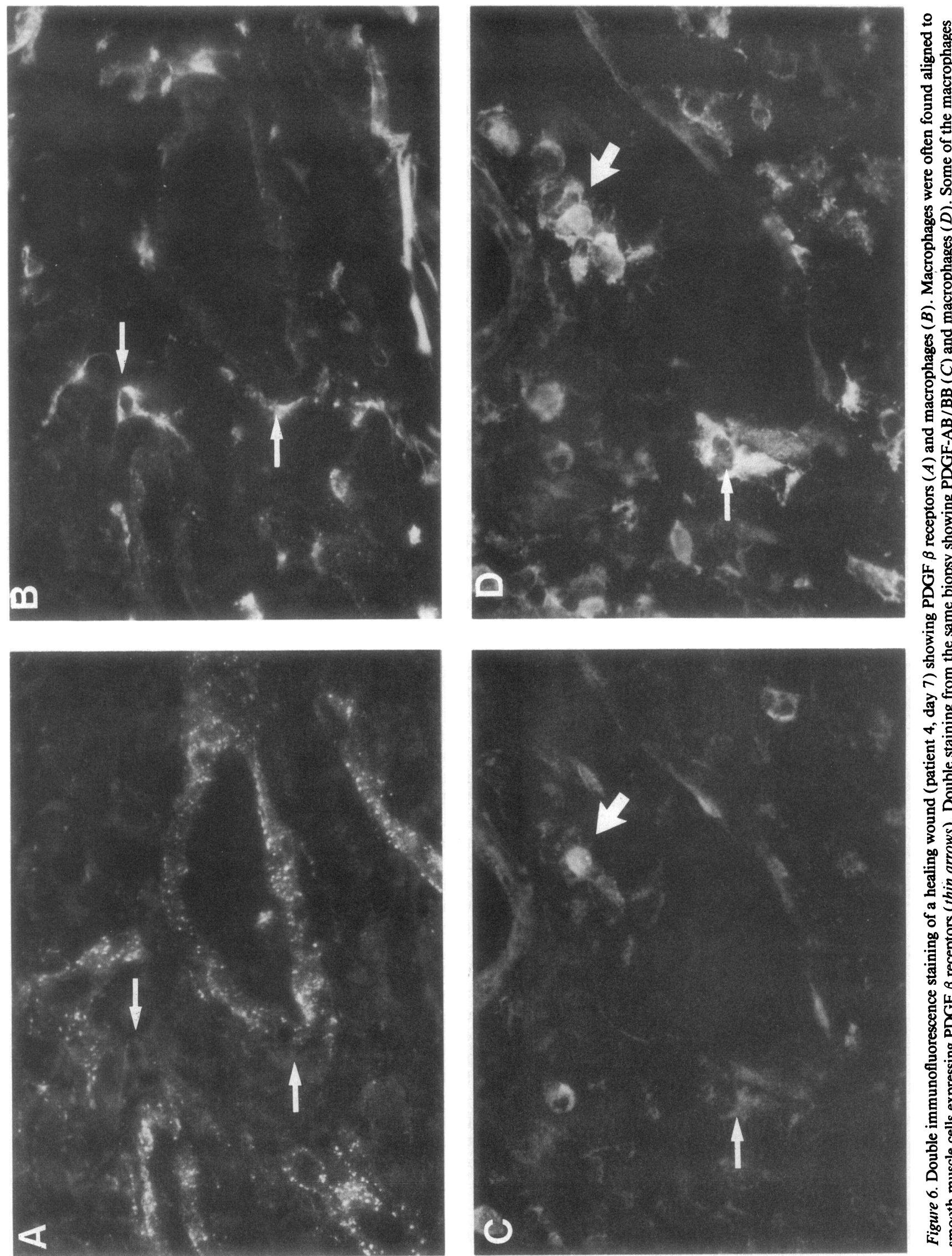

ह

돈

등

空

空

형

는

호

묵

के

을

与 0

施

\% 3

응

흘

]

है

8

8

옹

링

5

宐

웡

要

○瓷

눟

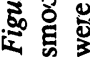



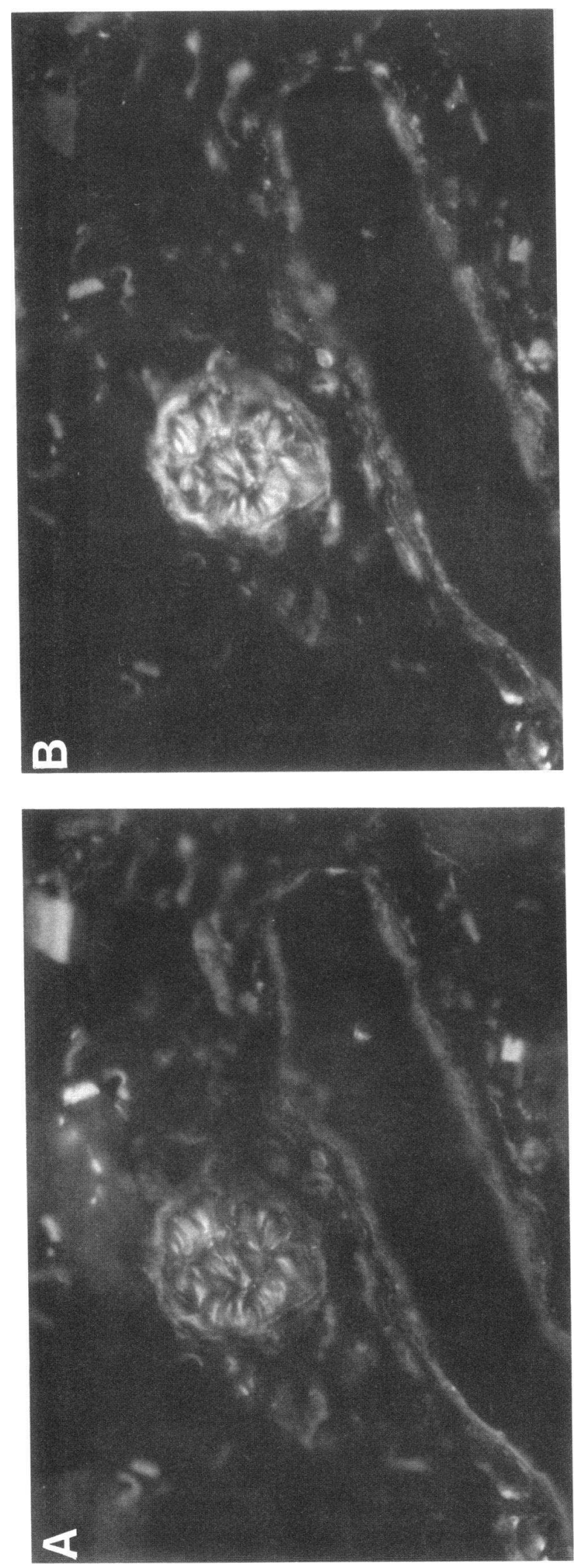

ings indicated that endothelial cells express PDGF $\beta$ receptors, it is also possible that all or some of the capillary cells expressing PDGF $\beta$ receptors were pericytes. Pericytes have earlier been reported to be absent from microvessels participating in angiogenesis (44), but a recent report has indicated their presence in newly formed capillaries in healing wounds (45). Regardless of what cell type(s) was/were responsible for the increased expression of PDGF $\beta$ receptors in wound capillaries, our results suggest that PDGF plays a role in one or more steps in angiogenesis.

Granular accumulations of PDGF $\beta$ receptors are characteristic of ligand-activated cultured fibroblasts, and it has been suggested that this represents internalized receptor-ligand complexes $(14,46)$. Cultured fibroblasts that had been stimulated by PDGF-BB, were, however, not stained by PDGF 007 IgG (unpublished observations), possibly because the epitope recognized by PDGF 007 is hidden in ligand-receptor complexes. The PDGF 007 antibody could thus not be used to elucidate if the granular accumulations of PDGF $\beta$ receptors observed in vivo were the result of PDGF-AB/BB stimulation. Further experimentation is thus needed to define the nature of the granular accumulations of PDGF $\beta$ receptors seen in the wound tissues.

In a recent study, Antoniades et al. (47) reported on the expression of PDGF/PDGF receptors in healing partial thickness skin wounds in pigs, a wound that mainly heals by reepithelialization. The authors observed a reversible expression of both c-sis/PDGF-B mRNA and PDGF-R mRNA, and of their corresponding proteins in both epithelial cells and in superficial dermal fibroblasts. We occasionally observed a positive staining with the PDGF 007 IgG and PDGFR-B2 IgG. This epithelial staining appeared haphazardly in our hands, however, and as this was occasionally observed also when sections were stained with various control antibodies, the specificity of this staining, with respect to the epithelium, could not be confirmed.

In the epidermal-dermal junction area, PDGF-AB/BBexpressing cells were present in specimens from both normal and wounded skin. Many of these cells also expressed HLA$\mathrm{DR}$, similarly to the PDGF-AB/BB-expressing cells located within the epidermis, cells that tentatively were identified as Langerhans cells. The exact nature of HLA-DR and PDGF$\mathrm{AB} / \mathrm{BB}-$ expressing cells in the epidermal-dermal junction area is not known. However, class II transplantation antigenexpressing cells, so-called "dendritic macrophages" are found in close association with dermal microvessels, especially in the superficial vascular plexus, of normal human skin (48). The function of PDGF-AB/BB-expressing cells at this anatomic site is not known; PDGF $\beta$ receptors are also expressed at this location (49), albeit to a low degree. It is tempting to speculate that PDGF may participate in migration of dendritic cells in normal skin. Indeed, it was recently demonstrated that Langerhans cells migrate from epidermis into dermis before leaving the skin (50).

The dermis of the wounds were infiltrated with PDGF-AB/ BB-positive CD68 macrophages as opposed to normal skin, where dermal infiltrates were absent or very low in number.

Figure 7. Double immunofluorescence staining (patient 4, day 3 ) showing neurofilament staining using the NN18 antibody $(A)$ to be strongly colocalized to staining for PDGF-AB/BB $(B)$. 
Table III. Quantitative Expression of PDGF-AB/BB (007+) Cells and CD68+ Macrophages Determined by Double Immunofluorescence Staining of Wound Biopsies Taken 6-8 d after Surgery from Eight Patients

\begin{tabular}{|c|c|c|c|c|c|c|c|c|c|c|c|}
\hline \multirow[b]{3}{*}{ Patient } & \multirow[b]{3}{*}{ Day } & \multirow{2}{*}{\multicolumn{2}{|c|}{$\begin{array}{l}007+/ \mathrm{CD} 68+\text { of } \\
\text { total CD68+ cells }\end{array}$}} & \multirow{2}{*}{\multicolumn{2}{|c|}{$\begin{array}{c}007+/ C D 68+\text { of } \\
\text { total } 007+\text { cells }\end{array}$}} & \multicolumn{6}{|c|}{ Counted cells per section } \\
\hline & & & & & & \multicolumn{2}{|c|}{$007+/$ CD68+ } & \multicolumn{2}{|c|}{ Total CD68+ } & \multicolumn{2}{|c|}{ Total $007+$} \\
\hline & & $\mathbf{s}$ & D & $\mathbf{S}$ & $\mathrm{D}$ & $\mathbf{S}$ & $\mathrm{D}$ & $\mathbf{S}$ & $\mathrm{D}$ & $\mathbf{S}$ & D \\
\hline & & \multicolumn{2}{|c|}{$\%$} & \multicolumn{2}{|c|}{$\%$} & & & & & & \\
\hline 1 & 8 & 34 & 66 & 45 & 54 & 82 & 50 & 239 & 76 & 181 & 93 \\
\hline 2 & 6 & 22 & 6 & 40 & 43 & 48 & 6 & 221 & 102 & 119 & 14 \\
\hline 4 & 7 & 30 & 49 & 21 & 50 & 37 & 53 & 125 & 108 & 177 & 108 \\
\hline 6 & 8 & 44 & 41 & 32 & 25 & 127 & 70 & 286 & 172 & 385 & 281 \\
\hline 7 & 7 & 50 & 61 & 37 & 38 & 88 & 69 & 177 & 112 & 237 & 180 \\
\hline 8 & 7 & 31 & 43 & 32 & 37 & 66 & 59 & 212 & 136 & 206 & 161 \\
\hline 9 & 6 & 49 & 47 & 52 & 48 & 41 & 39 & 84 & 83 & 79 & 82 \\
\hline 10 & 6 & 23 & 33 & 22 & 26 & 20 & 35 & 87 & 108 & 89 & 134 \\
\hline \multicolumn{2}{|c|}{ Mean \pm SD } & $35 \pm 11$ & $43 \pm 18$ & $35 \pm 11$ & $40 \pm 11$ & $64 \pm 34$ & $48 \pm 21$ & $179 \pm 74$ & $112 \pm 30$ & $184 \pm 99$ & $132 \pm 79$ \\
\hline \multicolumn{2}{|c|}{ Normal skin 1} & 17 & & 13 & & 36 & 0 & 207 & 0 & 279 & 0 \\
\hline \multicolumn{2}{|c|}{ Normal skin 2} & 14 & & 10 & & 23 & 0 & 162 & 0 & 231 & 0 \\
\hline \multicolumn{2}{|c|}{ Normal skin 3} & 14 & & 7 & & 23 & 0 & 169 & 0 & 346 & 0 \\
\hline \multicolumn{2}{|c|}{ Mean \pm SD } & $15 \pm 2$ & & $10 \pm 3$ & & $27 \pm 8$ & & $179 \pm 24$ & & $285 \pm 58$ & \\
\hline
\end{tabular}

Photographs were taken from 12-18 fields of vision at a magnification of 400 in each section with filters for either fluorescein or Texas red. All stained cells were counted. S, superficial dermis; D, deep dermis.

This suggests that infiltrating macrophages are the main source of newly expressed PDGF-AB/BB in wounds.

The observation that PDGF-AB/BB was expressed in nerve fibers is in line with previous observations showing that PDGF is produced by Schwann cells ( 51 ) and in neurons in the central nervous system (34). To investigate if PDGF-AB/BB was present in peripheral nerve fibers, we stained healthy sciatic nerve and jejunal specimens with the PDGF 007 antibody. It was found that a minority of the cells in the transversely sectioned sciatic nerve expressed PDGF-AB/BB. Structurally, the staining was localized in the neurolemma in some regions, while the location of the staining was not assessable in other areas (data not shown). In the intestinal specimens, there was weak but distinct staining for PDGF-AB/BB in the Auerbach and Meissner plexa (Lindmark, G., C. Sundberg, B. Glimelius, L. Påhlman, K. Rubin, and B. Gerdin, manuscript in preparation). These stainings show that peripheral nerve structures can indeed express PDGF-AB/BB. Identification of the cell types in the nerve fibers that express PDGF-AB/BB awaits further investigation, as well as the function of this pool of PDGF. A tempting suggestion is, however, that PDGF-AB/BB plays a role in nervous regulation of connective tissue cell activity.

In conclusion, the present study shows that $(a)$ there is an induction of PDGF $\beta$ receptors in wounds; ( $b$ ) PDGF $\beta$ receptor expression is predominantly seen in vessel walls; $(c)$ that macrophages carry PDGF-AB/BB to the wound, although $(d)$ there is also a constitutive expression of PDGF-AB/BB in certain nerve fibers. Although the function of the PDGF $\beta$ receptor system can not be elucidated at this point, the demonstration of both PDGF $\beta$ receptors and their ligands demonstrate that at least two of the prerequisites for a role of PDGF-AB / BB in wound healing are fulfilled. The main location of PDGF $\beta$ receptors to vessels suggests that PDGF contributes to the remodeling of the vasculature that occurs in the healing wound.

\section{Acknowledgments}

We gratefully acknowledge the technical assistance of Ms. Ann-Marie Gustafsson and Ms. Kristina Wiberg.

This study was supported by the Swedish Medical Research Council (B92-17X-09102-03A), the Swedish Cancer Foundation (2729B91-03XBC and 04PDF), Nordisk Insulinfond, Konung Gustaf V:s 80-årsfond, the Anna-Greta Crafoord Foundation, and the Lundberg Foundation.

\section{References}

1. Eckersley, J. R. T., and H. A. F. Dudley. 1988. Wounds and wound healing. Br. Med. Bull. 44:423-436.

2. Clark, R. A. 1989. Wound repair. Curr. Op. Cell Biol. 1:1000-1008.

3. Cromack, D. T., B. Porras-Reyes, and T. A. Mustoe. 1990. Current concepts in wound healing: growth factor and macrophage interaction. J. Trauma. 30:S129-S133.

4. Lynch, S. E., J. C. Nixon, R. B. Colvin, H. N. Antoniades. 1987. Role of platelet-derived growth factor in wound healing: synergistic effects of other growth factors. Proc. Natl. Acad. Sci. USA. 84:7696-7700.

5. Pierce, G. F., T. A. Mustoe, R. M. Senior, J. Reed, G. L. Griffin, A Thomason and T. F. Deuel. 1988. In vivo incisional wound healing augmented by platelet-derived growth factor and recombinant c-cis gene homodimeric proteins. J. Exp. Med. 167:974-987.

6. Pierce, G. F., J. E. Tarpley, D. Yanagihara, T. A. Mustoe, G. M. Fox, and A. Thomason. 1992. Platelet-derived growth factor (BB homodimer), transforming growth factor-beta 1 , and basic fibroblast growth factor in dermal wound healing. Neovessel and matrix formation and cessation of repair. Am. J. Pathol. 140:1375-1388.

7. Robson, M. C., L. G. Phillips, A. Thomason, L. E. Robson, and G. F. Pierce. 1992. Platelet-derived growth factor BB for the treatment of chronic pressure ulcers. Lancet. 339:23-25.

8. Heldin, C.-H., and B. Westermark. 1990. Platelet-derived growth factor: mechanism of action and possible in vivo function. Cell Regul. 1:555-566.

9. Raines, E. W., D. E. Bowen-Pope, and R. Ross. 1990. Platelet-derived growth factor. In Handbook of Experimental Pathology. Peptide Growth Factors and Their Receptors. M. B. Sporn and A. B. Roberts, editors. Springer Verlag, Heidelberg, Germany. 173-262.

10. Hart, C. E., M. Bailey, D. A. Curtis, S. Osborn, E. Raines, R. Ross, and J. W. Forstrom. 1990. Purification of PDGF-AB and PDGF-BB from human 
platelet extracts and identification of all three PDGF dimers in human platelets. Biochemistry. 29:166-172.

11. Ross, R., E. W. Raines and D. F. Bowen-Pope. 1986. Biology of plateletderived growth factor. Cell. 46:155-169.

12. Gullberg, D., A. Tingström, A.-C. Thuresson, L. Olsson, L. Terracio, T. K. Borg and K. Rubin. 1990. $\beta_{1}$ integrin-mediated collagen gel contraction is stimulated by PDGF. Exp. Cell Res. 186:264-272.

13. Clark, R. A., J. M. Folkvord, C. E. Hart, M. J. Murray and J. M. McPherson. 1989. Platelet isoforms of platelet-derived growth factor stimulate fibroblasts to contract collagen matrices. J. Clin. Invest. 84:1036-1040.

14. Tingström, A., C. Reuterdahl, P. Lindahl, C.-H. Heldin and K. Rubin 1992. Expression of PDGF $\beta$-receptors on human fibroblasts: regulation by macrophage-derived cytokines. J. Immunol. 148:546-554.

15. Siegbahn A., A. Hammacher, B. Westermark and C.-H. Heldin. 1990. Differential effects of the various isoforms of platelet-derived growth factor on chemotaxis of fibroblasts, monocytes and granulocytes. J. Clin. Invest. 85:916920.

16. Lepistö, J., M. Laato, H. Kujari, J. Niinikoski, C. Lundberg, B. Gerdin, and C.-H. Heldin. 1990. Effects of homodimeric isoforms of platelet-derived growth factor (PDGF-AA and PDGF-BB) on wound healing in rat. J. Surg. Res. In press.

17. Forsberg, K., I. Valyi-Nagi, C.-H. Heldin, M. Herlyn, and B. Westermark 1992. Novel role for PDGF in oncogenesis is suggested by the development of a vascular connective tissue stroma in xenotransplanted human melanoma producing PDGF-BB. Proc. Natl. Acad. Sci. USA. In press.

18. Kumkumian, G. K., R. Lafyatis, E. F. Remmers, J. P. Case, S.-J. Kim, and R. L. Wilder. 1989. Platelet-derived growth factor and IL-1 interactions in rheumatoid arthritis: regulation of synoviocyte proliferation, prostaglandin production, and collagenase transcription. J. Immunol. 143:833-837.

19. Heldin, C.-H., G. Bäckström, A. Östman, A. Hammacher, L. Rönnstrand, K. Rubin, M. Nistér, and B. Westermark. 1988. Binding of different dimeric forms of PDGF to human fibroblasts: evidence for two separate receptor types. EMBO (Eur. Mol. Biol. Organ.) J. 7:1387-1393.

20. Hart, C. E., J. W. Forstrom, J. D. Kelly, R. A. Seifert, R. A. Smith, R. Ross, M. J. Murray, D. F. Bowen-Pope. 1988. Two classes of PDGF receptors recognize different isoforms of PDGF. Science (Wash. DC). 240:1529-1531.

21. Eriksson, A., A. Siegbahn, B. Westermark, C.-H. Heldin, L. ClaessonWelsh. 1992. Platelet-derived growth factor $\alpha$ - and $\beta$-receptors activate unique and common signal tranduction pathways. EMBO (Eur. Mol. Biol. Organ.) J. 11:543-550.

22. Rönnstrand, L., L. Terracio, L. Claesson-Welsh, C.-H. Heldin and K. Rubin. 1988. Characterization of two monoclonal antibodies against the external domain of the receptor for platelet-derived growth factor. J. Biol. Chem. 263:10429-10435.

23. Rubin, K., L. Terracio, L. Rönnstrand, C.-H. Heldin, and L. Klareskog. 1988. Expression of platelet-derived growth factor receptors is induced on connective tissue cells during chronic synovial inflammation. Scand. J. Immunol. 27:285-294.

24. Rubin, K., A. Tingström, G. K. Hansson, E. Larsson, L. Rönnstrand, L. Klareskog, C.-H. Heldin, B. Fellström and L. Terracio. 1988. Induction of a B-type receptor for platelet-derived growth factor in vascular inflammation: possible implications for the development of vascular proliferative lesions. Lancet. i:1353-1356.

25. Terracio, L., L. Rönnstrand, A. Tingström, K. Rubin, L. Claesson-Welsh, K. Funa and C.-H. Heldin. 1988. Induction of platelet-derived growth factor receptor expression in smooth muscle cells and fibroblasts upon tissue culturing. J. Cell Biol. 107:1947-1957.

26. Reuterdahl, C., A. Tingström, L. Terracio, K. Funa, C.-H. Heldin and K. Rubin. 1991. Characterization of PDGF $\beta$-receptor expressing cells in the vasculature of the rheumatoid synovium. Lab. Invest. 64:321-329.

27. Wilcox, J. N., R. M. Smith, L. T. Williams, S. M. Schwartz, and D. Gordon. 1988. Platelet-derived growth factor mRNA detection in human atherosclerotic plaques by in situ hybridization. J. Clin. Invest. 82:1134-1143.

28. Smits, A., M. Kato, B. Westermark, M. Nistér, C.-H. Heldin and K. Funa. 1991. Neutropic activity of platelet-derived growth factor (PDGF) - rat neuronal cells possess functional PDGF $\beta$-receptors and respond to PDGF. Proc. Natl. Acad. Sci. USA. 88:8159-8163.

29. Fellström, B., L. Klareskog, C.-H. Heldin, E. Larsson, L. Rönnstrand, L. Terracio, G. Tufveson, J. Wahlberg and K. Rubin. 1989. Platelet-derived growth factor receptors in the kidney - Upregulated expression in renal inflammation Kidney Int. 36:1099-1102.

30. Remmers, E. F., H. Sano, R. Lafyatis, J. P. Case, G. K. Kumkumian, T. Hla, T. Meciag and R. L. Wilder. 1991. Production of platelet derived growth factor B chain (PDGF-B/c-sis) mRNA and immunoreactive PDGF B-like polypeptide by rheumatoid synovium: Coexpression with heparin binding acidic fibroblast growth factor-1. J. Rheumatol. 18:6-13.

31. Gay, S., R. E. Jones, G.-Q. Huang and R. E. Gay. 1989. Immunohistologic identification of platelet-derived growth factor (PDGF) and sis-oncgene expression in scleroderma. J. Invest. Dermatol. 92:301-303.

32. Ross, R., J. Masuda, E. W. Raines, A. M. Gown, S. Katsuda, M. Sasahara, L. T. Malden, H. Masuko and H. Sato. 1990. Localization of PDGF-B protein in macrophages in all phases of atherogenesis. Science (Wash. DC.). 248:10091012.

33. Sasahara, M., J. W. Fries, E. W. Raines, A. M. Gown, L. E. Westrum, M. P. Frosch, D. T. Bonthron, R. Ross and T. Collins. 1991. PDGF B-chain in neurons of the central nervous system, posterior pituitary, and in a transgenic model. Cell. 64:217-227.

34. Yeh, H.-J., K. G. Ruit, Y.-X. Wang, W. C. Parks, W. D. Snider and T. F. Deuel. 1991. PDGF-A-chain gene is expressed by mammalian neurons during development and in maturity. Cell. 6:209-216.

35. Shiraishi, T., S. Morimoto, K. Itoh, H. Sato, K. Sugihara, T. Onishi and T. Ogihara. 1989. Radioimmunoassay of human platelet-derived growth factor using monoclonal antibody toward a synthetic 73-97 fragment of its B-chain. Clin Chim. Acta. 184:65-74.

36. Juhlin, C., R. Holmdahl, H. Johansson, J. Rastad and G. Åkerström, G. 1987. Monoclonal antibodies with exclusive reactivity against parathyroid cells and tubule cells of the kidney. Proc. Natl. Acad. Sci. USA. 84:2990-2994.

37. Poulter, L. W., D. A. Campbell, C. Munro and G. Janossy. 1986. Discrimination of human macrophages and dendritic cells by means of monoclonal antibodies. Scand. J. Immunol. 24:351-357.

38. Hölthöfer, H., I. Virtanen, A.-L. Kariniemi, M. Hormia, E. Lindner and A. Miettinen. 1982. Ulex europeaus I lectin as a marker for vascular endothelium in human tissue. Lab. Invest. 47:60-66.

39. Claesson-Welsh, L., A. Eriksson, A. Morén, L. Severinsson, B. Ek, A. Östman, C. Betsholtz, and C.-H. Heldin. 1988. cDNA cloning and expression of a human platelet-derived growth factor (PDGF) receptor specific for B-chain containing PDGF molecules. Mol. Cell. Biol. 8:3476-3486.

40. Funa, K., L. Steinholtz, E. Nou and J. Bergh. 1987. Increased expression of $\mathrm{n}-\mathrm{Myc}$ in human small cell lung cancer biopsies predicts lack of response to chemotherapy and poor prognosis. Am. J. Pathol. 88:216-220.

41. Funa, K., V. Papanicolaou, C. Juhlin, J. Rastad, G. Ảkerström, C.-H. Heldin and K. Öberg. 1990. Expression of platelet-derived growth factor beta-receptors on stromal tissue cells in human carcinoid tumors. Cancer Res. 50:748753.

42. Smits, A., M. Hermansson, M. Nistér, I. Karnushina, C.-H. Heldin, B. Westermark, and K. Funa. 1989. Rat brain capillary endothelial cells express functional PDGF B-type receptors. Growth Factors. 2:1-8.

43. Bar, R. S., M. Boes, B. A. Booth, B. L. Dake, S. Henley and M. N. Hart. 1989. The effects of platelet-derived growth factor in cultured microvessel endothelial cells. Endocrinology. 124:1841-1848.

44. Orlidge, A. and P. A. D'Amore. 1987. Inhibition of capillary endothelial cell growth by pericytes and smooth muscle cells. J. Cell Biol. 105:1455-1462.

45. Schlingmann, R. O., F. J. R. Rietveld, F. Kwaspen, P. C. M. van der Kerkhof, R. M. W. de Waal and D. J. Ruiter. 1991. Differential expression of markers for endothelial cells, pericytes, and basal lamina in the microvasculature of tumors and granulation tissue. Am. J. Pathol. 138:1335-1347.

46. Sorkin, A., B. Westermark, C.-H. Heldin, L. Claesson-Welsh. 1991. Effect of receptor kinase inactivation on the rate of internalization and degradation of PDGF and the PDGF beta-receptor. J. Cell Biol. 112:469-478.

47. Antoniades, H. N., T. Galanopoulos, J. Neville-Golden, C. P. Kiritsy, and S. E. Lynch. 1991. Injury induces in vivo expression of platelet-derived growth factor (PDGF) and PDGF-receptor mRNAs in skin spithelial cells and PDGF mRNA in connective tissue fibroblasts. Proc. Natl. Acad. Sci. USA. 88:565-569.

48. Sontheimer, R. D. 1989. Perivascular dendritic macrophages as immunobiological constituents of the human dermal microvascular unit. $J$. Invest. Dermatol. 93:96S-101S.

49. Rubin, K., A. Tingström, C. Reuterdahl, M. Ljungström, and B. Gerdin. 1990. Aberrant expression of PDGF $\beta$-receptors in inflammatory disorders. In Growth Factors in Health and Disease. B. Westermark, C. Betsholtz, and B. Hökfelt, editors. Elsevier Science Publishers B. V., Amsterdam. 131-144.

50. Larsen, C. P., R. M. Steinman, M. Witmer-Pack, D. F. Hankins, P. J. Morris and J. M. Austyn. 1990. Migration and maturation of Langerhans cells in skin transplants and explants. J. Exp. Med. 172:1483-1493.

51. Eccelston, P. A., E. J. Collarini, K. R. Jessen, R. Mirsky and W. D. Richardson. 1990. Schwann cells secrete a PDGF-like factor: evidence for an autocrine growth mechanism involving PDGF. Eur. J. Neursci. 2:985-992. 